\title{
Intraspinal Neoplasm
}

National Cancer Institute

\section{Source}

National Cancer Institute. Intraspinal Neoplasm. NCI Thesaurus. Code C3382.

A primary or metastatic neoplasm that occurs within the spinal canal including the spinal cord and surrounding paraspinal spaces. 